\title{
The role of Galectin-3 in a-synuclein-induced microglial activation
}

\author{
Antonio Boza-Serrano ${ }^{1 *}$, Juan F Reyes ${ }^{2}$, Nolwen L Rey ${ }^{2,3}$, Hakon Leffler ${ }^{6}$, Luc Bousset ${ }^{8}$, Ulf Nilsson ${ }^{7}$, Patrik Brundin ${ }^{2,3}$,
} Jose Luis Venero ${ }^{5}$, Miguel Angel Burguillos ${ }^{4}$ and Tomas Deierborg ${ }^{1 *}$

\begin{abstract}
Background: Parkinson's disease (PD) is the most prevalent neurodegenerative motor disorder. The neuropathology is characterized by intraneuronal protein aggregates of a-synuclein and progressive degeneration of dopaminergic neurons within the substantia nigra. Previous studies have shown that extracellular a-synuclein aggregates can activate microglial cells, induce inflammation and contribute to the neurodegenerative process in PD. However, the signaling pathways involved in a-synuclein-mediated microglia activation are poorly understood. Galectin-3 is a member of a carbohydrate-binding protein family involved in cell activation and inflammation. Therefore, we investigated whether galectin-3 is involved in the microglia activation triggered by a-synuclein.
\end{abstract}

Results: We cultured microglial (BV2) cells and induced cell activation by addition of exogenous a-synuclein monomers or aggregates to the cell culture medium. This treatment induced a significant increase in the levels of proinflammatory mediators including the inducible Nitric Oxide Synthase (iNOS), interleukin 1 Beta (IL-1ß) and Interleukin-12 (IL-12). We then reduced the levels of galectin-3 expression using siRNA or pharmacologically targeting galectin-3 activity using bis-(3-deoxy-3-(3-fluorophenyl-1 H-1,2,3-triazol-1-yl)-3-D-galactopyranosyl)-sulfane. Both approaches led to a significant reduction in the observed inflammatory response induced by a-synuclein. We confirmed these findings using primary microglial cells obtained from wild-type and galectin-3 null mutant mice. Finally, we performed injections of a-synuclein in the olfactory bulb of wild type mice and observed that some of the a-synuclein was taken up by activated microglia that were immunopositive for galectin-3.

Conclusions: We show that a-synuclein aggregates induce microglial activation and demonstrate for the first time that galectin-3 plays a significant role in microglia activation induced by a-synuclein. These results suggest that genetic down-regulation or pharmacological inhibition of galectin-3 might constitute a novel therapeutic target in PD and other synucleinopathies.

Keywords: Microglia, Galectin-3, Neuroinflammation, a-synuclein, Parkinson's disease

\section{Introduction}

Parkinson's disease (PD) is a progressive neurodegenerative disorder clinically typified by bradykinesia, rigidity, postural instability and tremor, as well as a wide range of non-motor symptoms including constipation, bladder dysfunction and cognitive impairment [1]. Pathologically, PD is characterized by the formation of $\alpha$-synuclein aggregates commonly known as Lewy bodies and Lewy neurites [2], glial activation, brain inflammation and

\footnotetext{
*Correspondence: antonio.boza_serrano@med.lu.se; tomas.deierborg@med.lu.se ${ }^{1}$ Experimental Neuroinflammation Laboratory, BMC, Lund University, 22184 Lund, Sweden

Full list of author information is available at the end of the article
}

progressive dopaminergic cell degeneration [3]. While the majority of cases of PD appear to be sporadic, genetic mutations or multiplications of the $\alpha$-synuclein gene (SNCA) lead to the onset of familial PD $[4,5]$.

$\alpha$-Synuclein is a soluble protein composed of 140 amino acids found predominantly in presynaptic terminals where it is thought to play a role in development and plasticity [6-9]. In addition, $\alpha$-synuclein is highly expressed in immune cells, including T-cells, B-cells, natural killer cells and monocytes [10]. Recent studies suggest that $\alpha$-synuclein can transfer from one cell to another and promote the self-aggregation and thus possibly contributing to disease propagation $[7,11-14]$.
C Biomed Central

(c) 2014 Boza-Serrano et al.; licensee BioMed Central Ltd. This is an Open Access article distributed under the terms of the Creative Commons Attribution License (http://creativecommons.org/licenses/by/4.0), which permits unrestricted use, distribution, and reproduction in any medium, provided the original work is properly credited. The Creative Commons Public Domain Dedication waiver (http://creativecommons.org/publicdomain/zero/1.0/) applies to the data made available in this article, unless otherwise stated. 
While microglial activation has been suggested to play major role in the neurodegenerative process in PD $[15,16]$, the signaling pathways that mediate this process are still poorly understood. For instance, Codolo and colleagues have recently demonstrated that $\alpha$-synuclein monomers and fibrils induce Interleukin $1 \beta$ (IL-1 $\beta$ ) release from monocytes [17] via the Toll-like receptor 2 (TLR2). Moreover, Kim and colleagues have suggested that oligomeric forms of $\alpha$-synuclein specifically activate TLR2 [18]. However, the TLR4 has also been implicated in $\alpha$-synuclein-induced inflammation [19]. Moreover, it has been shown that the effects on cell activation and the subsequent inflammatory response can vary with the source/ species of $\alpha$-synuclein (mammalian cell-derived vs recombinant) and/or the type of protein used (wild type or mutant) [20]. Moreover, the molecular state of the protein used (monomeric, oligomeric or fibrillar) can also play a role in the magnitude of the inflammatory response [18]. Indeed, depending on the microenvironment/insult, activated microglia cells can adopt one of two wellcharacterized profiles, namely a classical (pro-inflammatory, M1) or an alternative (anti-inflammatory, M2) profile $[21,22]$. In these two different states, activated microglia release different factors and express different surface proteins that allow them to sense the microenvironment and coordinate the inflammatory response. In the pro-inflammatory (M1) profile, microglial cells release different pro-inflammatory molecules, e.g. Tumor Necrosis Factor- $\alpha$ (TNF- $\alpha)$, IL-1 $\beta$, Interleukin-12 (IL-12), Interferon- $\gamma($ IFN- $\gamma$ ) or Nitric oxide (NO), which decrease neuronal survival $[23,24]$. The alternative profile, however, is characterized by release of anti-inflammatory factors $(e$. g. Interleukin-4 (IL-4), Interleukin-13 (IL-13) or Transforming Growth factor- $\beta$ (TGF- $\beta$ )) which reduce microglial activation [25]. While different pathways have been suggested to be involved in $\alpha$-synuclein-mediated activation including the ERK 1/2, p38 MAPK, inflammasome or the NF- $\kappa \beta$ pathway $[17,26]$, the involvement of galectin-3 and microglial activation remains to be elucidated. Galectin-3, which is identical to the commonly used macrophage marker Mac-2, is an inflammatory mediator known to be highly expressed in some activated inflammatory cells, including microglia. Galectin-3 levels are increased in several conditions including encephalomyelitis, traumatic brain injury, experimental allergic encephalitis (EAE) and ischemic brain injury [27,28]. However, a possible role for $\alpha$-synuclein induced galectin- 3 activation during the inflammatory process in $\mathrm{PD}$ has yet to be elucidated.

Galectin-3 is a member of the $\beta$-galactoside-binding lectin family defined by their typical carbohydrate recognition domains (CRDs) [29,30]. Galectin-3 plays a role in different biological activities, including cell adhesion, proliferation, clearance, apoptosis, cell activation, cell migration, phagocytosis and inflammatory regulation [27,31-37]. Galectin-3 is found both intra- (in cytoplasm and nucleus) and extracellularly in different cell types and is suggested to play both pro-inflammatory and antiinflammatory roles which depend on the cell type and insult provided [31,36,38,39]. In this study, we investigated whether galectin-3 is involved in microglial activation induced by $\alpha$-synuclein proteins. Therefore, we exposed BV2 and primary microglia cells to monomeric and aggregated forms of recombinant $\alpha$-synuclein and specifically studied the inflammatory response. We then determined the effects of microglial activation following downregulation of galectin-3 using a specific pharmacological inhibitor or genetic down regulation using siRNA. We then monitored the effects of different forms of $\alpha$ synuclein on galectin-3-null mice primary microglial cultures. Finally, we determined whether $\alpha$-synuclein injections into the olfactory bulb of wild type mice result in microglia activation and galectin-3 protein expression.

\section{Materials and methods \\ Animals}

For primary microglial cultures, galectin-3 null mice [40] with a pure C57BL/6 background were obtained from Dr. K. Sävman from Gothenburg University. For intracerebral injections, 3-month-old female mice C57BL/ 6J were purchased from Charles River Laboratories and housed them under a $12 \mathrm{~h}$ light/12 h dark cycle with access to food and water and libitum at Lund university (Sweden). All procedures were carried in accordance with the international guidelines and were approved by the Malmö-Lund Ethical Committee for Animal Research in Sweden (M479-12).

\section{Genotyping}

The genotype of gal3-/- and gal3+/+ mice was determined by an integrated extraction and amplification kit (Extract-N-Amp ${ }^{\mathrm{sm}}$, Sigma-Aldrich). The PCR consisted of $94^{\circ} \mathrm{C}$ for $5 \mathrm{~min}$, then 40 cycles with denaturation at $94^{\circ} \mathrm{C}$ for $45 \mathrm{sec}$, annealing at $55^{\circ} \mathrm{C}$ for $30 \mathrm{sec}$, and elongation at $72^{\circ} \mathrm{C}$ for $1.5 \mathrm{~min}$. The primers (CyberGene, Solna, Sweden) used were as follows: galectin-3 common 5CAC GAA CGT CTT TTG CTC TCT GG-3'), gal3-/5-GCT TTT CTG GAT TCA TCG ACT GTG G-3' (single band of $384 \mathrm{bp}$ ) and gal3+/+5-TGA AAT ACT TAC CGA AAA GCT GTC TGC-3' (single band of $300 \mathrm{bp}$ ) [41]. We separated the PCR products by gel electrophoresis labeled with ethidium bromide and visualized in a CCD camera (SONY, Tokyo, Japan).

\section{Cell cultures and treatment}

We cultured murine microglial cells (BV2 cell line) in Dulbecco's modified Eagle's medium (DMEM) containing 10\% Fetal Bovine Serum (Invitrogen) with $100 \mathrm{U} / \mathrm{ml}$ 
Penicillin and $100 \mathrm{U} / \mathrm{ml}$ Streptomycin (Invitrogen) in 5\% $\mathrm{CO}_{2}$ atmosphere at $37^{\circ} \mathrm{C}$ in T75 flasks (Nunc, Thermo Scientific) and passaged at confluency. BV2 cells were seeded at a concentration of $2 \times 10^{5}$ cells/well in 24 wells plate (Nunc, Thermo Scientific) then treated with $\alpha$ synuclein monomers or aggregates at different concentrations $(5,10$ and $20 \mu \mathrm{M})$ or LPS (Sigma-Aldrich) at $1 \mu \mathrm{g} / \mathrm{ml}$. All treatments were conducted for $12 \mathrm{~h}$.

\section{Primary cell cultures}

Primary microglia cultures from wild-type (WT) (C57BL/6) or galectin-3 knockout (KO) mice, cells were prepared from postnatal day 1-3 and cultured as previously described [42]. Briefly, the cerebral cortex were dissociated in ice cold Hank's Balance Salt Solution without bivalent ions (HBSS, Invitrogen), Trypsin (0.1\%) (Invitrogen) and DNase (0.05\%) (Sigma-Aldrich). The cells were then plated in T75 flask with $10 \mathrm{ml} /$ flask of Dulbecco's modified Eagle's medium (DMEM, Invitrogen) containing 10\% Fetal Bovine Serum (Invitrogen) with 100 U/ml Penicillin and $100 \mathrm{U} / \mathrm{ml}$ Streptomycin (Invitrogen) in $5 \% \mathrm{CO}_{2}$ atmosphere at $37^{\circ} \mathrm{C}$. After 14 days, cells were harvested in the medium by smacking the flask 10-20 times and plated in 96 wells plates at a density of $2 \times 10^{4}$ cells/well. The primary cultures were then treated with $\alpha$-synuclein aggregates at different concentrations $(50 \mathrm{nM}, 200 \mathrm{nM}, 1,5$, and $20 \mu \mathrm{M})$.

\section{a-synuclein aggregate generation}

Briefly, human $\alpha$-synuclein was purified using the heat treatment, ion exchange, and gel filtration chromatography as previously described [43]. $\alpha$-synuclein monomers were placed on an orbital shaker at $250 \mathrm{rpm}$, shaking the monomers for 5 days at $37^{\circ} \mathrm{C}$ in sterile PBS. After 5 days of incubation, the protein aggregates were sonicated using a Branson Sonifier 250 (All-Spec, Willington, US) with the following conditions: 3/9 output and 30/100 Duty Cycle. We tested the composition of our aggregates and monomers using Western Blot analysis and transmission electron microscopy (TEM) (FEI, Einhofen Holland). We performed negative stain of monomeric and sonicated aggregated forms of $\alpha$-synuclein by using $2 \%$ uranyl acetate in water. The concentration of endotoxin was measured in our protein preparations using the Limulus amebocyte lysate assay (Chromogenic Endotoxin Quantification Kit, Thermo Scientific, US). We detected very low levels of endotoxin $(0.14 \mathrm{ng}$ of LPS $/ \mathrm{ml})$ that was unable to influence on the microglial activation (data not shown).

\section{Galectin-3 inhibitor}

We used a small inhibitory molecule for galectin-3 activity, bis-(3-deoxy-3-(3-fluorophenyl-1H-1,2,3-triazol-1-yl)$\beta$-D-galactopyranosyl)-sulfane $\left(K_{d}=14 \quad n M\right)$ [44-46] as pre-treatment 30 minutes $(5,25,50$ and $100 \mu \mathrm{M})$ before cells were treated with $\alpha$-synuclein (monomers or aggregates) or for $12 \mathrm{~h}$ along with $\alpha$-synuclein (monomers or aggregates) at $100 \mu \mathrm{M}$.

\section{Transfection conditions}

Transfection of BV2 cells was carried out using Lipofectamine 2000 following the manufacturer's recommendation (Life Technologies). Non-targeting control and galectin-3 siRNAs were obtained from Dharmacon. (SMART pool) siRNA sequence used: siLGal3S3(1) J-041097-09 GAGAG AUACCCAUCGCUUU, siLGal3S3(2) J-041097-10 ACUU CAAGGUUGCGGUCAA, siLGal3S3(3) J-041097-11 AC AGUGAAACCCAACGCAA, siLGal3S3(4) J-041097-12 GGAUGAAGAACCUCCGGGA.

\section{Western blot analysis}

Briefly, proteins were loaded on 4-20\% Mini-Protean TGX Precast Gels (Bio-Rad) then transferred to Nitrocellulose membranes (Bio-Rad) using Trans-Blot Turbo System (Bio-Rad). Membranes were then blocked with $10 \%$ Casein (Sigma-Aldrich) diluted in PBS (tablets, Sigma-Aldrich). After blocking, we incubated membranes, with primary antibodies at $4^{\circ} \mathrm{C}$ over night. We then incubated membranes with peroxidase secondary antibody (Vector Labs) and blots were developed using Clarity Western ECL Substrate (Bio-Rad) and protein levels were normalized to actin.

\section{Antibodies}

Antibodies used for this study; anti-rabbit iNOS primary Antibody (1:5000, Santa Cruz), Anti-rat Galectin-3 Antibody (1:3000, M38 clone from Hakon Leffler's lab), Anti-mouse Actin antibody 1:8000 (Sigma-Aldrich), Antihuman Synuclein antibody 1:3000 (Life Technologies).

\section{Cytokines analysis}

We measured the cytokine levels from BV2 conditioned medium and primary microglial cells after $12 \mathrm{~h}$ treatment. We used the ultrasensitive Th1/Th2 cytokine multiplex plate to measure IFN- $\gamma$, IL-1 $\beta$, IL-2, IL-4, IL-5, IL-8, IL-10, IL-12, IL-6 and TNF- $\alpha$ (Meso Scale Discovery, Rockville, USA) according to the manufacturer's recommendations. The plates were analyzed using with the plate reader SECTOR Imager 6000 (Meso Scale Discovery, Rockville, USA). The conditioned medium was snap frozen on dry ice and kept in $-80^{\circ} \mathrm{C}$ freezer prior analysis.

\section{Viability assay}

Cell viability was performed by measuring mitochondrial activity (mitochondrial dehydrogenase) in living cells using XTT (2,3-Bis-(2-methoxy-4-nitro-5-sulfophenyl]-2Htetrazolium-5-carboxyanilide salt) (Sigma-Aldrich). The assay was performed following manufacturer's protocol on 
a 96-well plate (Biochrom Asys Expert 96 micro plate reader, Cambridge, UK).

\section{Olfactory bulb recombinant a-synuclein injections}

We analyzed brain sections from mice injected into the olfactory bulb with different $\alpha$-synuclein species (monomeric, oligomeric and fibrillar $\alpha$-synuclein) as previously described [47]. Briefly, $\alpha$-synuclein was produced in Escherichia coli and purified and filtered as described previously $[47,48]$. Oligomers were obtained by incubating soluble $\alpha$-synuclein at 4 degrees for 7 days without shaking, in $50 \mathrm{mM}$ Tris- $\mathrm{HCl}$, and then separated from monomers by size exclusion chromatography. Fibrils were obtained from incubation of monomers under continuous shaking at $37^{\circ} \mathrm{C}$, and samples were assessed by electron microscopy. $\alpha$-synuclein was then tagged with ATTO-550 as described previously [47]. We injected $\alpha-$ synuclein monomers, oligomer and fibrils $(1 \mathrm{mg} / \mathrm{mL} ; 0.8$ $\mathrm{uL}$ ) stereotactically into the olfactory bulb of mice (coordinates AP: $+5.4 \mathrm{~mm}, \mathrm{~L}:-0.75 \mathrm{~mm}, \mathrm{DV}:-1 \mathrm{~mm}$ relative to bregma and dural surface). After injection, $12 \mathrm{~h}$ and $72 \mathrm{~h}$, we perfused the mice transcardially with saline solution, followed by $4 \%$ paraformaldehyde (PFA) in phosphate buffer. We dissected the brains and post-fixed them for $2 \mathrm{~h}$ in PFA $4 \%$ followed by saturation in 30\% sucrose solution. We then cut brains into $30 \mu \mathrm{m}$ freefloating coronal sections, as shown previously [47].

\section{Immunofluorescence on mouse brain tissue}

We stained free-floating coronal sections of the olfactory bulb from injected mice with primary antibodies: anti-rat Galectin-3 (1:300) and anti-rabbit Iba-1 (1:500, Wako/ Nordic labs) with appropriate secondary antibodies Alexa488 anti-rat, Alexa-647 anti-rabbit (raised in goat, 1:400, Invitrogen). We then analyzed these sections with a confocal laser microscope ZEISS LSM 510 (Switzerland), equipped with Ar and HeNe Lasers.

\section{Phagocytic Assay}

We measured the microglial phagocytosis using a phagocytosis assay kit (Cayman Chem, USA) according to the protocol provided by the manufacturer. We plated $5 \times$ $10^{4}$ cells/well in 96 well plates for $12 \mathrm{~h}$ before treating the cells with $\alpha$-synuclein $(20 \mu \mathrm{M})$ for additional $12 \mathrm{~h}$. Thereafter, IgG-FITC beads were added with or without galectin-3 inhibitor for $12 \mathrm{~h}$ and the phagocytic ability was then analyzed (FluoStar Optima, BMG, LabTech, Sweden).

\section{Statistical analysis}

The differences between experimental groups were analyzed (unless otherwise stated) with one-way ANOVA with Tukey's post hoc test, two-way ANOVA Dunnett's post hoc test or t-test as indicated in the figure legends.
$\mathrm{P}<0.05$ was considered as statistically significant. We used the statistical software GraphPad PRISM 6.0 (San Diego, CA, USA). Data is represented as mean \pm S.E.M. A minimum of 3 different independent experiments were performed for all the in vitro experiments.

\section{Results \\ Exogenous a-synuclein proteins promote microglial activation}

To assess whether $\alpha$-synuclein can activate microglial cells in vitro, we first generated recombinant $\alpha$-synuclein and induced protein aggregates as previously reported [43]. We then characterized the $\alpha$-synuclein species by Western blot and electron microscopy analysis (Additional file 1: Figure S1A-C). Our data demonstrate that $\alpha$-synuclein in the aggregated state is composed of a mixture of monomers, oligomers and to a lesser extent, fibrillar $\alpha$-synuclein species (Additional file 1: Figure S1D). We then assessed the inflammatory response by exposing microglial cells to different concentrations of monomeric or aggregated forms of $\alpha$-synuclein $(5,10$ and $20 \mu \mathrm{M})$ for $12 \mathrm{~h}$, the time period at which the temporal iNOS expression response following LPS treatment is the highest [49]. Using these conditions, we identified a concentration-dependent upregulation of iNOS expression following both monomeric and aggregated forms of $\alpha$-synuclein (Figure 1A and $\mathrm{B}$, respectively). At the highest concentration used however $(20 \mu \mathrm{M}), \alpha$-synuclein aggregates induced a 3fold higher iNOS expression compared to monomeric $\alpha$ synuclein (Figure 1A and B). These results indicate that our $\alpha$-synuclein proteins successfully induce microglial activation [17].

\section{Pro-inflammatory cytokine levels increase after a-synuclein treatment}

Following $\alpha$-synuclein treatment, we observed a concentration dependent up-regulation of cytokine secretion that includes TNF- $\alpha$, IL-2 and IL-12 (Figure 2A-C). These results suggest that microglial activation induced by $\alpha$ synuclein aggregates promote a pro-inflammatory cascade similar to that observed in PD $[24,50]$.

\section{Inhibition of galectin-3 prevents iNOS expression and reduce pro-inflammatory cytokines release in BV2 microglial cells}

First, we assessed the effect of pharmacological inhibition of galectin-3 prior to $\alpha$-synuclein-induced microglial activation. To this end, microglial cells were pre-treated with a galectin-3 inhibitor for 30 minutes (5, 25,50 and $100 \mu \mathrm{M}$ ) then washed and exposed to monomeric or $\alpha$-synuclein aggregates $(20 \mu \mathrm{M})$ then we assessed the levels of iNOS expression. After pharmacological inhibition of galectin-3, we observed a significant inhibition of $\alpha$-synuclein-induced microglial activation (as 
A
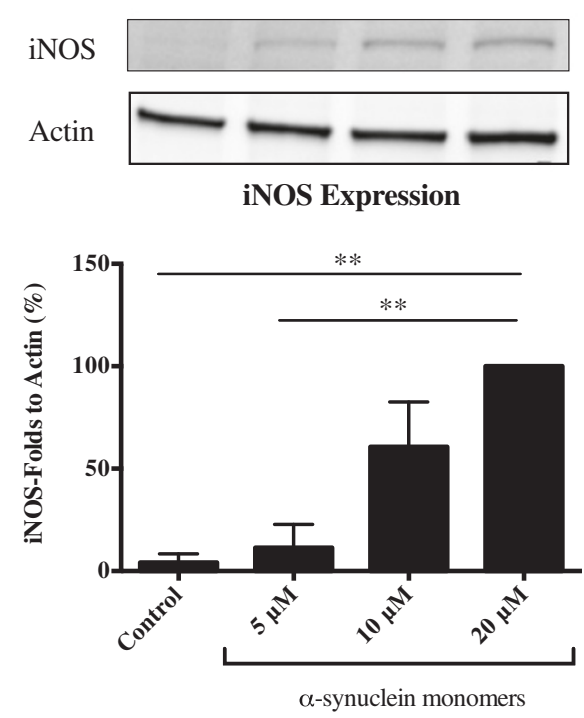

$\mathrm{C}$

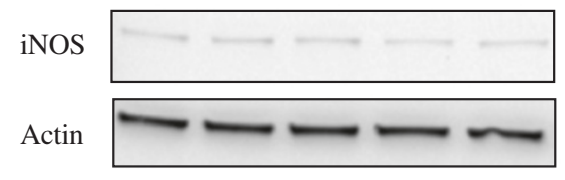

iNOS Expression

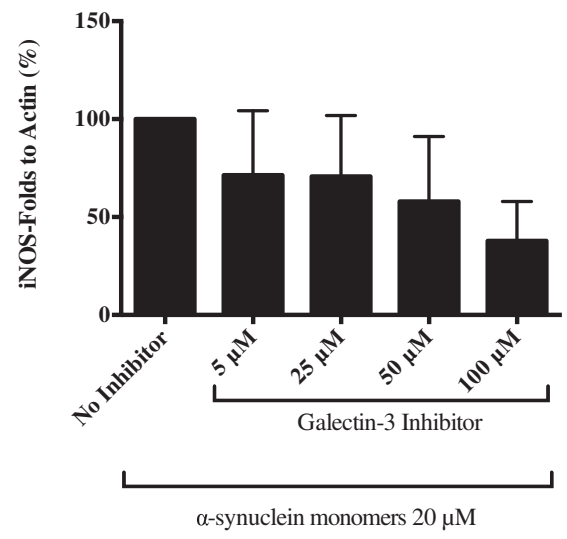

\section{B}

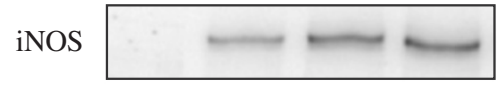

Actin

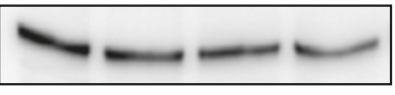

iNOS Expression

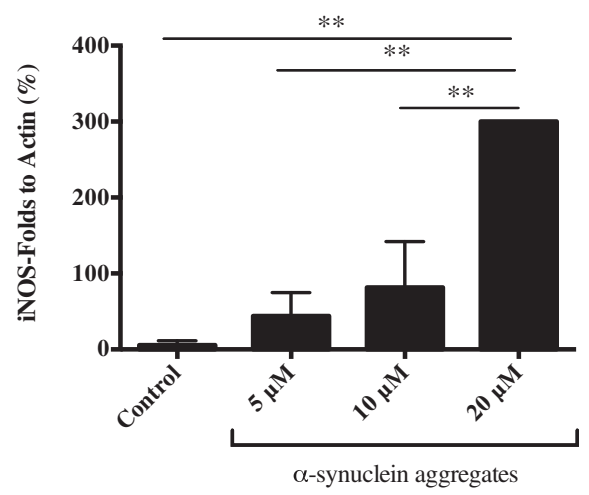

D
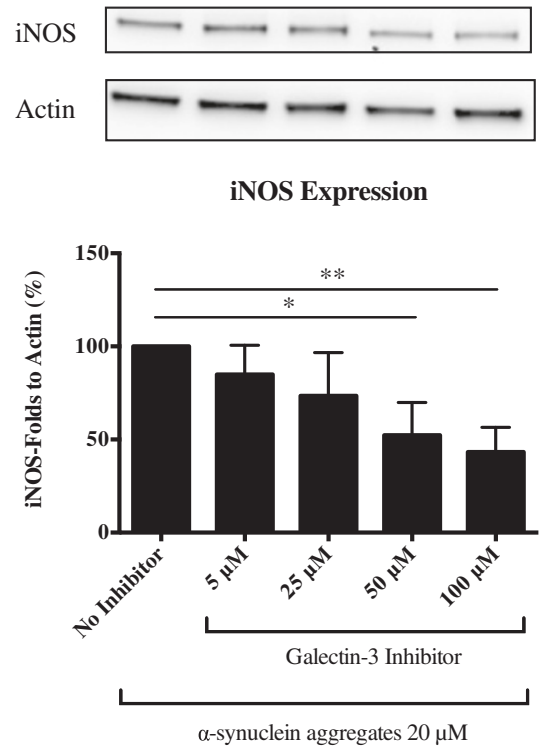

Figure 1 Microglial activation by a-synuclein and inhibition by galectin-3 inhibitor. We measured iNOS expression by western blot in microglial cells after $12 \mathrm{~h}$ incubation with a-synuclein monomers (A) and a-synuclein aggregates (B) using different concentrations, $5 \mu \mathrm{M}, 10 \mu \mathrm{M}$ and $20 \mu \mathrm{M}$. iNOS was significantly up regulated with both protein preparations of a-synuclein. a-synuclein aggregates (B) induced a 3-fold higher activation compared to monomers (A). To determine the role of galectin-3 we used a pre-treatment, incubating the galectin-3 inhibitor for $30 \mathrm{~min}$ and then we incubated for $12 \mathrm{~h}$ the cells with a-synuclein, monomers or aggregates, using the highest concentration, $20 \mu \mathrm{M}$. The lower iNOS expression induced by a-synuclein monomers was not significantly inhibited by pharmacological inhibition of galectin-3 (C). iNOS expression induced by a-synuclein aggregates (D) was inhibited by more than $50 \%$ using $100 \mu \mathrm{M}$ of the inhibitor. We use the highest iNOS response in each experiment as an internal control to evaluate the response to the other concentrations. Western blot analysis displays iNOS and $\beta$-actin protein levels. One-way ANOVA, ${ }^{*} P<0.05,{ }^{* *} P<0.01, n=3$, mean \pm S.E.M.

shown by the lack of iNOS expression) in a concentrationdependent manner with more than $50 \%$ iNOS downregulation following 50 and $100 \mu \mathrm{M}$ treatment, a result that was specific to $\alpha$-synuclein aggregates (Figure $1 \mathrm{C}$ and D). Next, we assessed the effect of pharmacological inhibition of galectin-3 for $12 \mathrm{~h}$ along with the $\alpha$-synuclein aggregates. Pharmacological inhibition of galectin-3 for $12 \mathrm{~h}$ resulted in a higher inhibition (85\%) of $\alpha$-synuclein- 


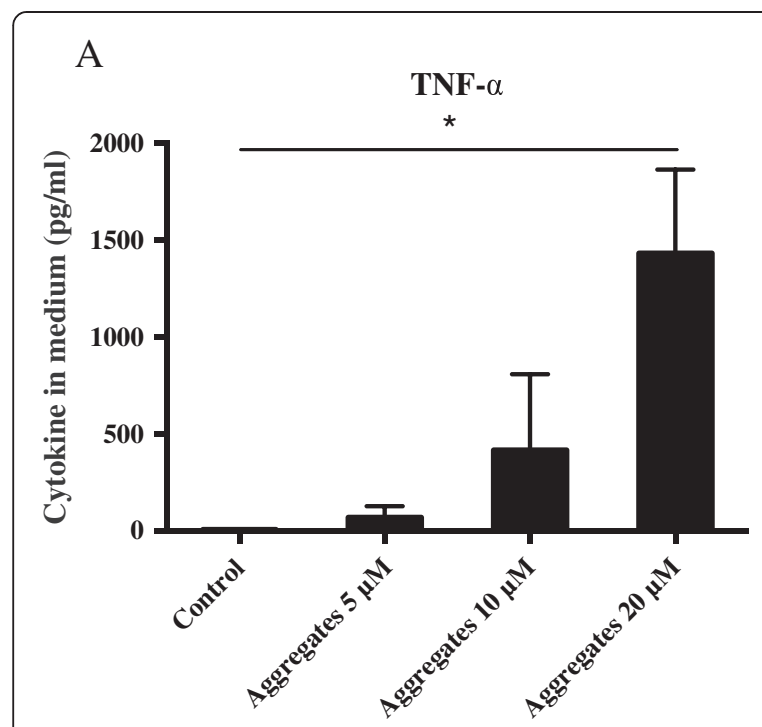

B

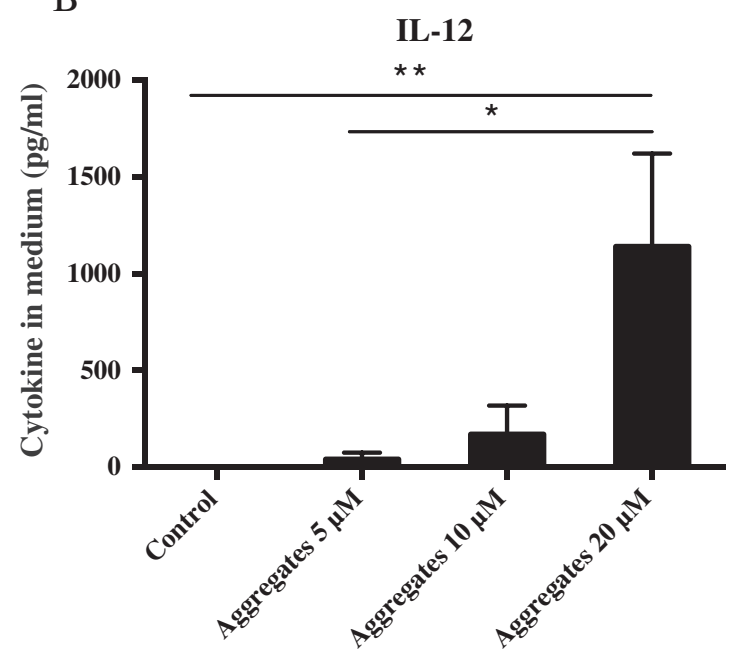

C

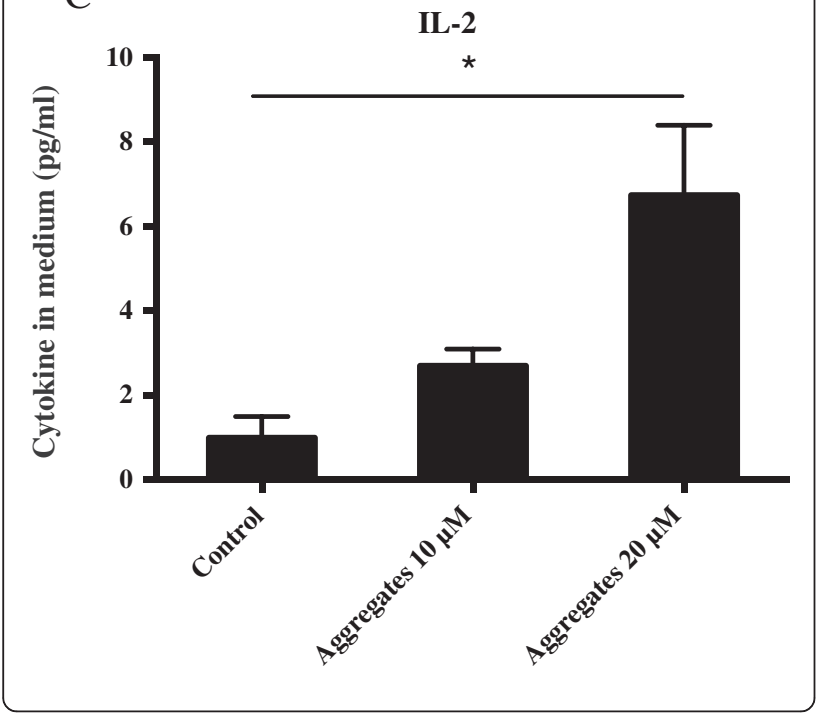

Figure 2 Increased cytokine levels in BV2 microglia culture medium after a-synuclein activation. Cytokine levels in BV2 microglia culture medium after $12 \mathrm{~h}$ incubation with a-synuclein aggregates at concentrations of 5, 10 and $20 \mu \mathrm{M}$. a-synuclein aggregates induced a significant increase in cytokine levels of the proinflammatory cytokines TNF- $a$ (A), IL-12 (B) and IL-2 (C). One-way ANOVA, ${ }^{*} P<0.05,{ }^{*} P<0.01, n=3$, mean \pm S.E.M.

induced microglial activation (iNOS expression, Figure 3A). We then measured the cytokine levels in the medium after galectin-3 inhibition and $\alpha$-synuclein treatment for $12 \mathrm{~h}$ and observe a clear reduction in the pro-inflammatory cytokines IL-12, IL-6 and TNF- $\alpha$ (Figure 3B).

\section{Galectin-3 inhibition does not impair cell viability}

As shown in figure S2, inhibition of galectin-3 does not affect cell viability when cells are treated alone or in combination with $\alpha$-synuclein aggregates for $12 \mathrm{~h}$. Interestingly, $\alpha$-synuclein treatment of microglial cells increased mitochondrial activity with or without the inhibitor, suggesting an increased metabolic need that may be triggered by $\alpha$-synuclein aggregates.

\section{Galectin-3 knockdown in BV2 microglial cells down-regulates iNOS expression and pro-inflammatory cytokine release}

To further test the role of galectin-3 in microglial activation, we genetically down-regulated galectin-3 expression in BV2 cells using small interfering RNA (siRNA) (Figure 4A). We then treated the cells with $\alpha$-synuclein aggregates and analyzed the iNOS expression levels using Western blot analysis (Figure 3B). As expected, downregulation of galectin-3 significantly reduced iNOS protein expression levels (Figure 4B). Next, we measured the cytokine levels in BV2 cells genetically down regulated with small interfering RNA (siRNA) targeting galectin-3 and treated with $\alpha$-synuclein aggregates. Genetic downregulation of galactin-3 also showed a reduction in TNF- $\alpha$ and IL-10 compared to cells treated with control siRNA (Figure 4C). Taken together these results demonstrate that down-regulation of galectin- 3 reduces $\alpha$-synuclein induced microglial activation and significantly lowers iNOS protein expression and cytokine up-regulation.

\section{Pharmacological intervention of galectin-3 reduces the microglial phagocytic activity}

To test the implications on the phagocytic ability of microglial cells in our $\alpha$-synuclein activation model, we treated BV2 cells with the galectin-3 inhibitor for either 30 minutes or $12 \mathrm{~h}$ together with $\alpha$-synuclein aggregates. As expected, activated microglial cells show a higher phagocytic activity whereas no differences were observed in the phagocytic ability using the inhibitor as a pretreatment (data not shown). As shown in Figure 5, the 

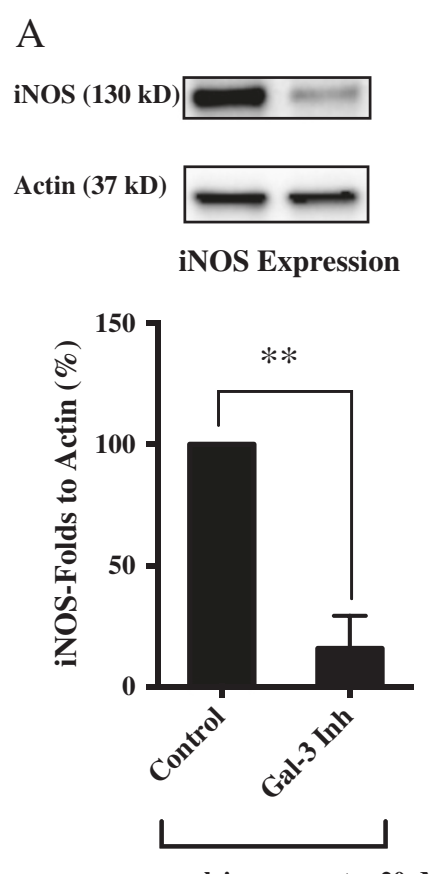

$\alpha$-synuclein aggregates $20 \mu \mathrm{M}$
$\mathrm{B}$
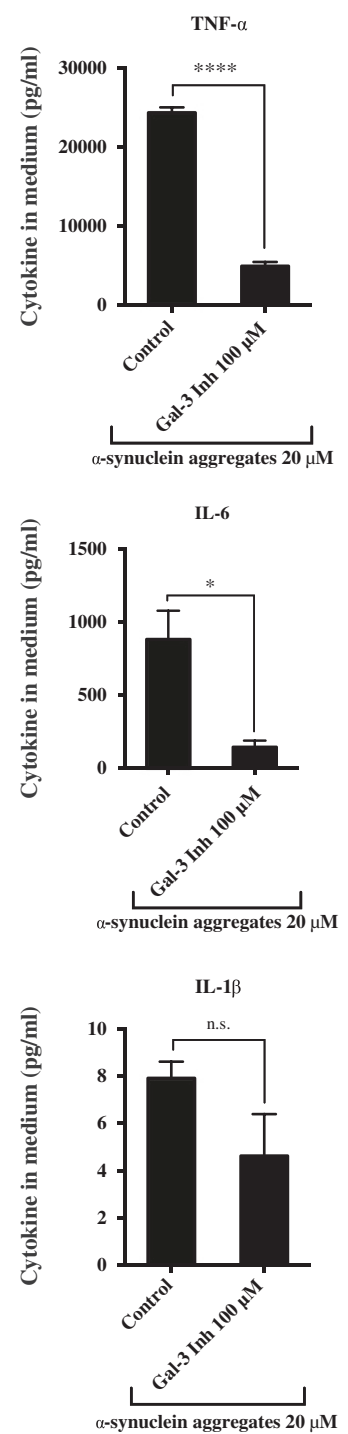
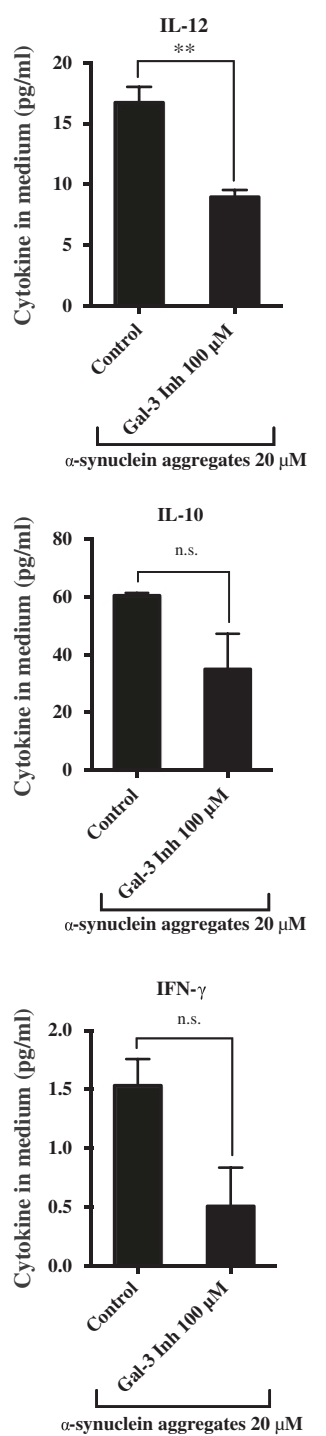

Figure 3 Inhibition of microglial activation by galectin-3 inhibitor. To determine the role of galectin-3 we used a treatment, incubating the galectin-3 inhibitor along with a-synuclein aggregates for $12 \mathrm{~h}$ at $20 \mu \mathrm{M}$. We determine by western blot the iNOS expression induced by a-synuclein aggregates. iNOS expression was inhibited by more than $80 \%$ using $100 \mu \mathrm{M}$ of the inhibitor $(\mathbf{A})$. The cytokines levels were measure and TNF-a, IL-12 and IL-6 were down regulated when using the inhibitor for 12 along with a-synuclein aggregates (B). We use the highest iNOS response in each experiment as an internal control to evaluate the response to the other concentrations. Western blot analysis displays iNOS and $\beta$-actin protein levels. One-way ANOVA, ${ }^{*} P<0,05,{ }^{* *} P<0.01$, $\left.{ }^{* * *} P<0,0001\right) n=3$, mean \pm S.E.M.

phagocytic ability of microglia was reduced to control levels during the experiment when cells are treated with the inhibitor for $12 \mathrm{~h}$. As expected, treating the cells with recombinant galectin-3 proteins up-regulates microglial phagocytic activity to levels similar to cells treated with $\alpha$-synuclein aggregates (Figure 5). Importantly, we did not detect any synergic effect when cells were treated with galectin- 3 and $\alpha$-synuclein aggregates. These results suggest that induction of phagocytosis is an important aspect of microglial activation by $\alpha$ synuclein aggregates and that galectin-3 plays an important role in cell activation and phagocytosis. These results are in in line with previous studies showing that phagocytosis is a central part in $\alpha$-synuclein induced inflammation [17].

\section{Microglia from galectin-3 knockout mice display iNOS down-regulation following a-synuclein activation}

Next we examined the iNOS levels in primary microglial cells, we analyzed the conditioned medium after cells been treated with $\alpha$-synuclein aggregates for $12 \mathrm{~h}$. In line with our BV2 iNOS cytokine data (Figure 1), we 

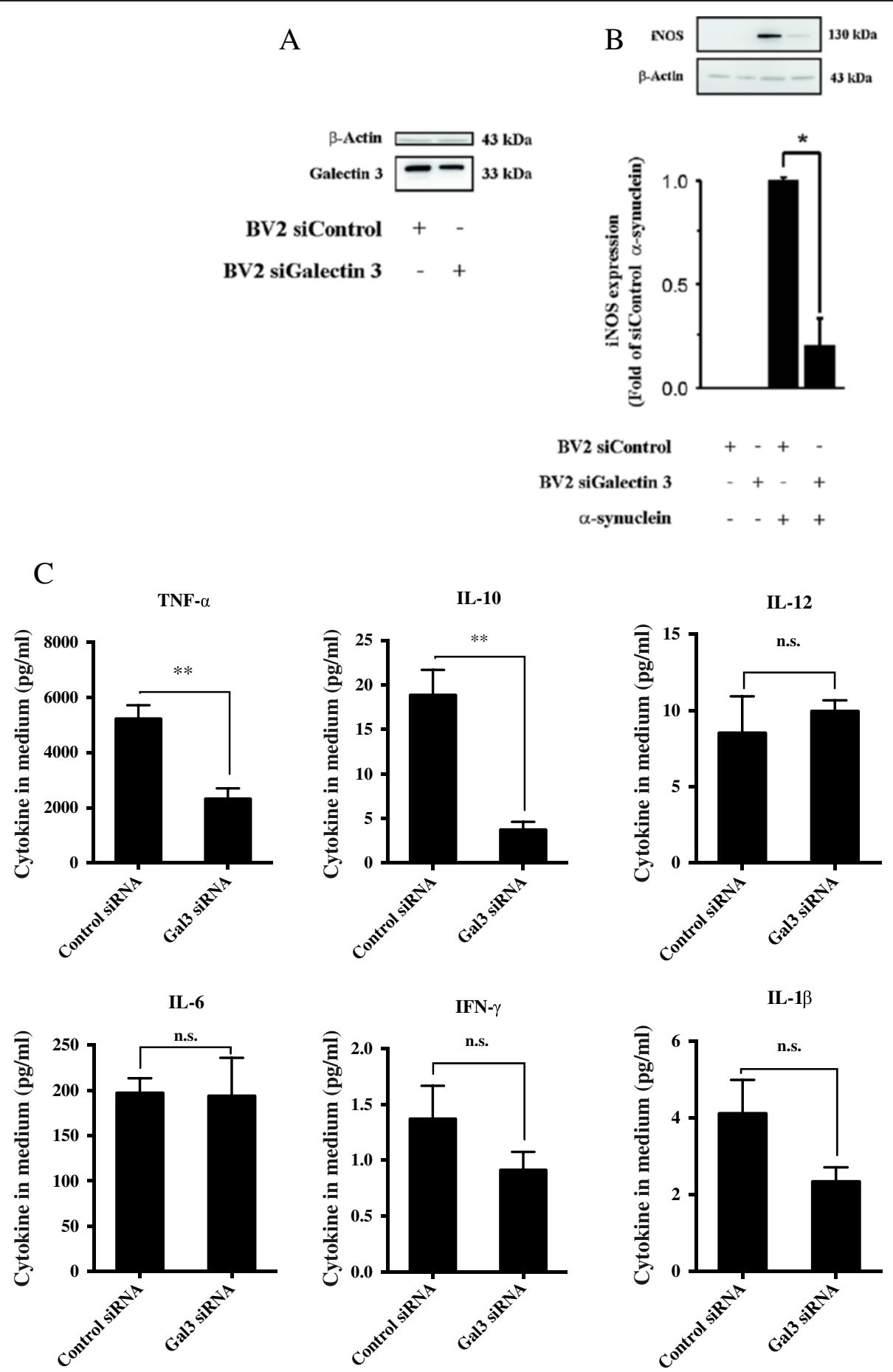

Figure 4 Galectin-3 siRNA reduces microglial activation induced by a-synuclein aggregates. BV2 microglia activated by $20 \mu \mathrm{M}$ of a-synuclein aggregates for $12 \mathrm{~h}$ show a robust iNOS down regulation by $80 \%$ when galectin-3 is knocked down by siRNA (B). Knock down efficiency of galectin-3 siRNA (A). The cytokines levels from BV2 cells treated medium was measured after $12 \mathrm{~h}$ incubation with a-synuclein aggregates and we found significant reduction in TNF- $a$ and IL-10 (C). Western blot analysis showing iNOS and $\beta$-actin protein levels. t-test, One-Way ANOVA. ${ }^{*} P<0.05,{ }^{*} P<0,01 n=3$, mean \pm S.E.M.

identified a robust up-regulation iNOS following $\alpha$-synuclein challenge (Figure 6A). Importantly, galectin-3 knockout microglial cells showed a complete abrogation of iNOS protein expression (Figure 6B). This data clearly demonstrated that iNOS regulation maybe dependent on galectin-3. 


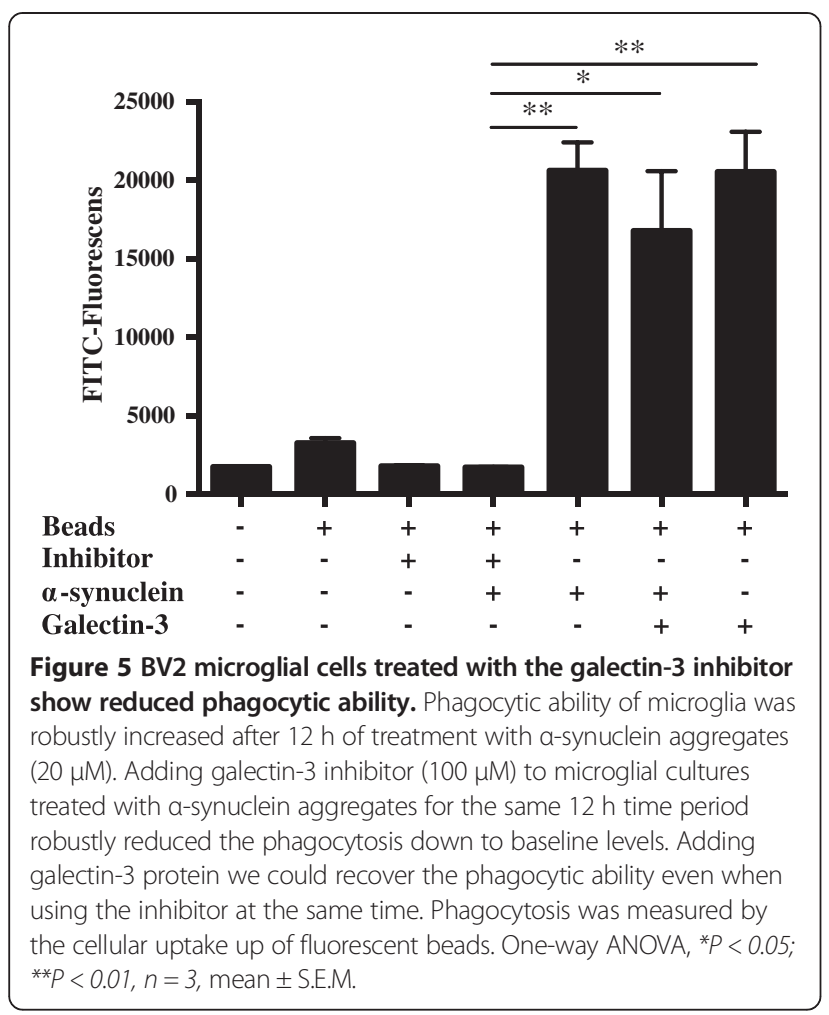

\section{Microglia from galectin-3 knockout mice show a down-regulation of pro-inflammatory cytokines following a-synuclein activation}

To examine the cytokine levels in primary microglial cells, we analyzed the conditioned medium after cells were treated with $\alpha$-synuclein aggregates. In line with our BV2 cytokine data (Figure 2), we identified a robust up-regulation of pro-inflammatory cytokines that included IL-12 and IL-1 $\beta$ and IFN- $\gamma$ as well as the antiinflammatory cytokine IL-4 (Figure 6C). Importantly, galectin-3 KO microglial cells showed a significant reduction in IL-1 $\beta$ (55\%) and IL-12 (75\%) cytokine release when compared to wild type microglia (Figure 6C). However, no differences were observed in IFN- $\gamma$ or the anti-inflammatory cytokine IL-4. Taken together, our results indicate that galectin-3 is involved in the proinflammatory activation of specific inflammatory pathways that involve the IL-1 $\beta$ and IL-12 cytokines.

\section{Olfactory bulb injections of recombinant a-synuclein}

To confirm the expression of galectin- 3 in microglial cells following activation with $\alpha$-synuclein in vivo, we injected $\alpha$-synuclein tagged with ATTO-550 in a monomeric, oligomeric or fibrillar state within the olfactory bulb of wild type mice. We then performed immunofluorescence analysis and identified activated microglial cells (Iba-1) that were positive for galectin-3 following $\alpha$-synuclein injections (Figure 7). While microglial cells were able to take up all three different forms of $\alpha$-synuclein injected, differences in the molecular species taken up by microglia cells were shown to vary with time. Indeed, at $12 \mathrm{~h}$ post injection, we identified activated microglial cells containing monomers and oligomers with up-regulated galectin-3 expression (Figure 7A). In contrast, limited galectin-3 expression was observed upon fibrillar $\alpha$ synuclein (Figure 7A). These results may be due to the limited uptake of the fibrillar forms of $\alpha$-synuclein [47], or the time required to phagocyte the fibrillar $\alpha$ synuclein species. Interestingly, at $72 \mathrm{~h}$ post injection, monomeric $\alpha$-synuclein did not induce galectin-3 expression, whereas oligomers and fibrils showed a clear galectin-3 up-regulation (Figure 7B). Taken together, our data demonstrate that microglial cells take up $\alpha$-synuclein in vivo and display a microglia phenotype that is galectin3 positive.

\section{Discussion}

We demonstrate for the first time that galectin-3; a carbohydrate-binding protein is an immune modulator that plays an important role in the $\alpha$-synuclein-induced activation of microglia. We identified a profound inflammatory inhibition of microglia cells by genetic downregulation or pharmacological inhibition of galectin-3 or by using galectin-3 knockout primary microglia following activation by $\alpha$-synuclein aggregates. In agreement with these results, prior work suggests that $\alpha$-synuclein oligomers are neurotoxic and induce a strong inflammatory response in microglia cells, exceeding that seen after exposure to $\alpha$-synuclein monomers [18]. Interestingly, Tokuda and colleagues have identified elevated levels of $\alpha$-synuclein oligomers and an increased oligomers/total- $\alpha$-synuclein ratio in the cerebrospinal fluid in PD patients, suggesting that $\alpha$-synuclein oligomers may contribute to the progression of PD [51].

Recent discoveries have also demonstrated that $\alpha$ synuclein can transfer from one cell to another and seed endogenous protein aggregation within the recipient cell in a prion-like fashion [13]. Besides spreading from neuron to neuron, $\alpha$-synuclein can also spread from neurons to glial cells as shown previously in vitro and in vivo [52]. Due to the presence of $\alpha$-synuclein in the extracellular milieu, several novel treatment strategies focusing on reducing the $\alpha$-synuclein levels have been proposed including immunotherapy [53,54], delivery of $\alpha$-synuclein degrading enzymes [55] or altering microglial activity [56]. Indeed, microglial activation has been linked to several neurodegenerative disorders [57] and therefore, a pharmacological intervention on the inflammatory response exerted by microglia may be a promising therapeutic target. In attempts to reduce microglial activity, several different inflammatory pathways have been targeted in earlier studies. For example peroxiredoxin 2, which inhibits the mitogen-activated 
A

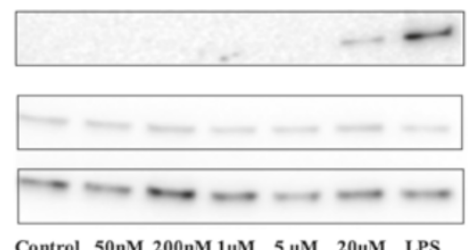

B

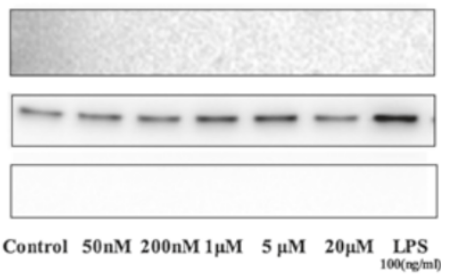

C

IL-12

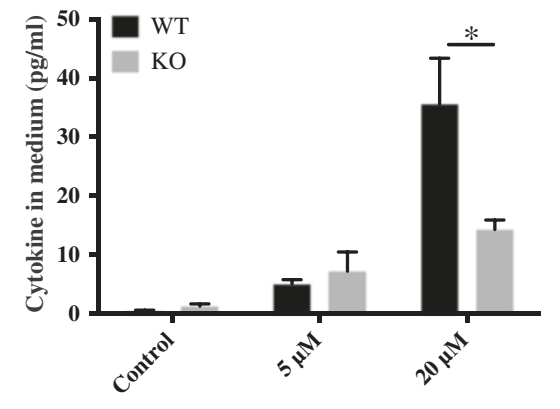

IFN- $\gamma$

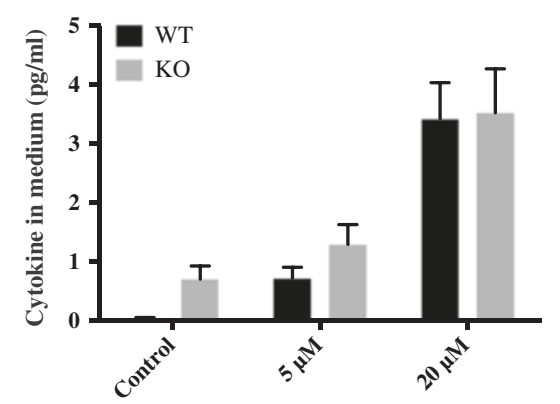

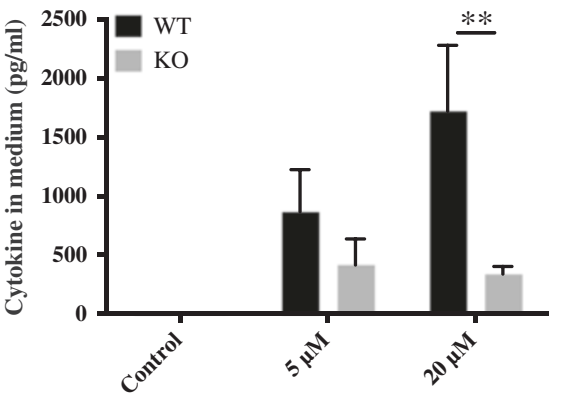

IL-4

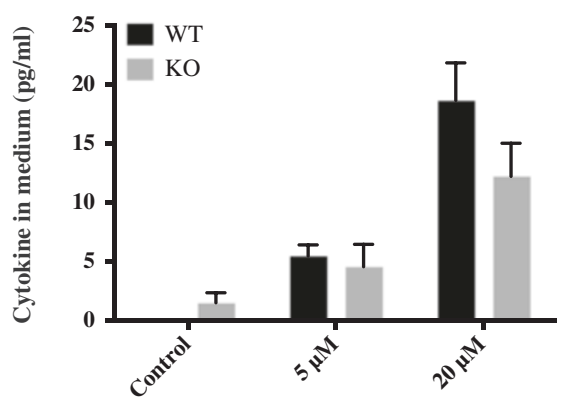

Figure 6 Abrogation of iNOS proteins level and pro-inflammatory cytokines reduction in primary microglial cells from galectin-3 knockout mice after activation with a-synuclein. Primary microglial culture from wild-type mice shows robust iNOS expression following exposure of $20 \mu \mathrm{M}$ a-synuclein aggregates, or LPS (100 ng/ml), for $12 \mathrm{~h}$ (A). Lower concentrations of a-synuclein aggregates, $5 \mu \mathrm{M}$ and below, failed to induce iNOS expression in wild- type microglia (A). Primary microglia from galectin-3 knockout mice completely lack iNOS up regulation following exposure of $20 \mu \mathrm{M}$ a-synuclein aggregates for $12 \mathrm{~h} \mathrm{(B).} \mathrm{Cytokine} \mathrm{levels} \mathrm{in} \mathrm{culture} \mathrm{medium} \mathrm{from} \mathrm{primary} \mathrm{microglial} \mathrm{cells} \mathrm{were} \mathrm{measured}$ after $12 \mathrm{~h}$ incubation with a-synuclein aggregates. Treatment of wild-type microglia with 5 and $20 \mu \mathrm{M}$ a-synuclein aggregates for $12 \mathrm{~h}$ induced increased levels of IL-1 $\beta, I L-12$, IFN- $\gamma$ and IL-4 (C). Treatment of galectin-3 knockout microglia for $12 \mathrm{~h}$ reduced levels of IL-1 $\beta$ IL-12 using $20 \mu \mathrm{M}$ a-synuclein aggregates. Cytokine levels of IFN- $\gamma$ and IL-4 did not change in galectin-3 knockout compared to wild-type microglia. Two-way ANOVA, ${ }^{*} P<0.05,{ }^{*} P<0.01, n=5$, mean \pm S.E.M.

protein kinase and the transcription factor nuclear factor-kB (NF-kB), have shown to be effective [58]. Additionally, minocycline, one of the most used inhibitors for microglia activation has also been suggested to specifically inhibit the M1 phenotype [59]. Moreover, inhibition of NADPH oxidase 2 (Nox2) has also been shown to reduce microglial activation in $\alpha$-synuclein-induced inflammation model [60].

In this study, we used a small molecule inhibitor targeting galectin-3 and found that it inhibited microglial activation following challenge with aggregated $\alpha$-synuclein. Galectin-3 inhibitor has been successfully tested in other pathological conditions with evidence for a rate-limiting role of galectin-3 [46]. For example, in a mouse model of hepatitis, the galectin-3 inhibitor attenuated liver damage and proinflammatory $\mathrm{T}$ cell-mediated cytokine release (IFN- $\gamma$ - and IL-17- and IL-4 producing CD4+ T cells). The same inhibitor also increased the number of $\mathrm{T}$ cells producing the anti-inflammatory IL-10 while promoting activation of M2 phenotype in macrophages [45]. Recently, the inhibitor was shown to support the survival of pancreatic beta cells in an apoptotic model induced by proinflammatory cytokines TNF- $\alpha+$ IFN- $\gamma+$ IL-1 $\beta$ [44]. In our current model system, we observed an up-regulation 


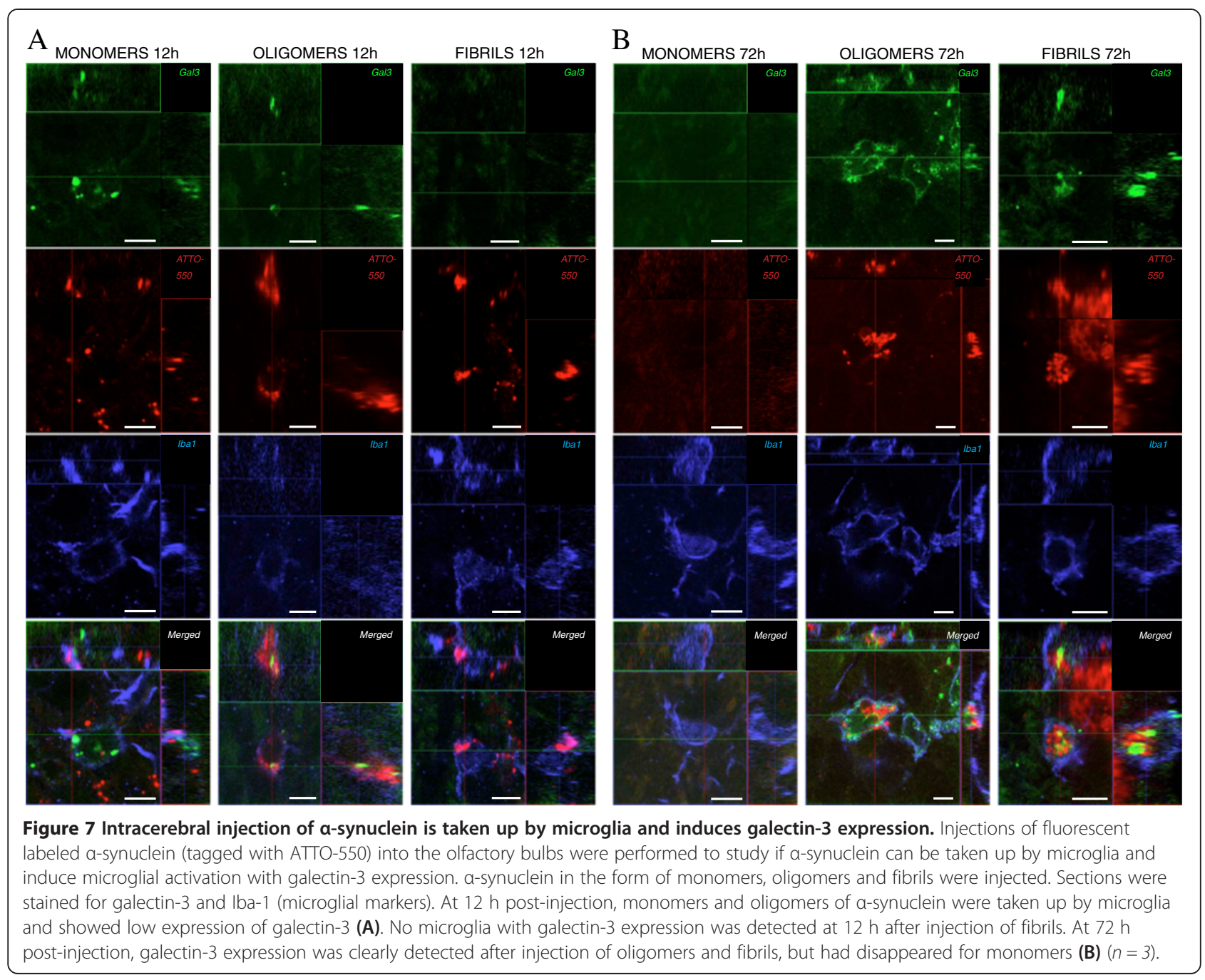

of both pro and anti-inflammatory cytokines released from primary and BV2 microglial cells. After analysis, we detected a significant up regulation of pro-inflammatory cytokines TNF- $\alpha$, IL-2 and IL-12. Using either, the galectin-3 inhibitor for $12 \mathrm{~h}$ or genetic down-regulation using siRNA we found a significant down-regulation in different proinflammatory molecules that include iNOS and TNF- $\alpha$, molecules involved in the nuclear factor-kappa Beta (NF$\kappa \beta)$ pathway [61]. Using primary microglial cells derived from galectin-3 knockout mice, we identified a significant reduction in IL-12 and IL- $1 \beta$ release compared to wild type microglia. Interestingly, the absence of galectin-3 did not significantly affect the levels of IFN- $\gamma$ or cytokines related to alternative activation pathway (e.g. IL-4) suggesting that, in response to $\alpha$-synuclein, galectin- 3 plays a specific inflammatory role in microglial activation. Such selective role for galectin-3 is noteworthy as galectin-3 regulates traffic of specific membrane glycoproteins (e.g. receptors) [62]. While the regulatory roles of galectins vary between different cell types, this variation is likely due to the galectin type and/or the type of glycans expressed in a particular cell [63]. Our findings support the notion that the inflammatory modulation exerted by galectin-3 is related to specific inflammatory pathways.

We have identified a robust reduction of IL-12 cytokine level in the primary galectin-3 $\mathrm{KO}$ microglia when compared to wild type microglial cells. The IL-12 production is regulated through multiple pathways that include: NF- $\kappa \beta$, p38 mitogen-activated protein (MAP) kinase, cyclic adenosine monophosphate (cyclic AMP)modulating molecules and nitric oxide (NO) [64]. In line with our findings, several studies have shown a relationship between iNOS inhibition and a down-regulation of IL-12 expression [65]. Our results demonstrate a profound iNOS expression and a pro-inflammatory cytokines reduction upon galectin-3 knockdown, gene deletion or pharmacological inhibition, suggesting that the NF-k $\beta$ pathway may indeed be the effector pathway for galectin3. Moreover, the inflammasome, which generates mature IL-1 $\beta$ by activating caspase- 1 , has also been shown to be 
associated with microglial activation [66-69]. Indeed, recent findings suggest that this inflammatory signaling pathway is activated by the phagocytosis of $\alpha$-synuclein $[17,70]$. For instance, Freeman and colleagues described a specific interaction between galectin-3 and the phagosomes/lysosomes containing $\alpha$-synuclein [70]. We observed a remarkable $80 \%$ inhibition of $\alpha$-synuclein-induced phagocytosis by pharmacological inhibition of galectin-3. This suggests that galectin-3 regulates $\alpha$-synuclein-induced activation of microglia. On the other hand, increased phagocytosis of $\alpha$-synuclein by microglia within the substantia nigra could potentially reduce the load of toxic $\alpha$-synuclein species [71].

Indeed, we found galectin-3 immunoreactive microglia $12 \mathrm{~h}$ following injection of monomeric or oligomeric $\alpha$ synuclein proteins. However, we did not detected galectin-3 immunoreactive cells after fibril injections at the same time points suggesting different up-take dynamics or intracellular processing [47]. At later time point however, $\alpha$-synuclein fibrils and oligomers induced a robust galectin-3 immunoreactivity whereas monomers failed to induce a similar response indicating that monomers may be processed intracellular within $72 \mathrm{~h}$ without galectin-3 activation.

\section{Conclusions}

We have demonstrated that galectin-3 is an important molecule that contributes to full-blown microglial activity upon exposure to $\alpha$-synuclein aggregates. Genetic ablation, down-regulating galectin-3, or pharmacologically inhibition of galectin-3, resulted in a profound downregulation of microglial activation (i.e. reduced levels of iNOS, TNF- $\alpha$, IL-12, IL-1B and the phagocytic ability of microglia). Following injections of $\alpha$-synuclein species in the olfactory bulb, we observe an up-regulation of galectin-3 in microglial cells that had taken up the injected $\alpha$-synuclein, providing further support for the importance of galectin-3 in vivo.

\section{Additional files}

Additional file 1: Figure S1. Characterization of a-synuclein monomers and a-synuclein aggregates. We analyzed our a-synuclein preparations using Transmission Electron Micrograph (TEM) (A-C) and western blot (D). Images from TEM showed small molecules in the preparation of monomers (B) and larger molecule arrangements in our aggregated preparations (C), suggested monomeric and oligomeric/fibril proteins structures, respectively. Western Blot analysis confirmed monomeric protein in our monomer protein preparations. In our protein aggregate preparation we found oligomers and monomers and a small fraction of fibrils $(>250 \mathrm{kDa}) . \mathrm{D}_{1}$, normal exposure time; $D_{2}$, long exposure time.

Additional file 2: Figure S2. Survival assay showed no impairment in microglia viability after treatment with a-synuclein and/or galectin-3 inhibitor. BV2 cell viability was used to study the effect of a-synuclein aggregates and the galectin-3 inhibitor, alone or in combination after $12 \mathrm{~h}$ culturing. a-synuclein aggregates did not negatively affect the cell viability. In fact, a-synuclein aggregates (with or together without inhibitor) showed increased mitochondrial activity. XTT Cell Viability Assay Kit was used. One-way ANOVA, ${ }^{*} P<0.05, n=4$, mean \pm S.E.M.

\section{Abbreviations}

PD: Parkinson disease; KO: Knockout; WT: Wild-type; iNOS: Inducible nitric oxide synthase; TLR: Toll like receptor; IFN-ץ: Interferon gamma; TNF-a: Tumor necrosis factor alpha; IL: Interleukin; MAPK: Mitogen-activated protein kinases; ERK: Extracellular signal-regulated kinases; NF-kß: Nuclear factor kappa-lightchain-enhancer of activated B cells.

\section{Competing interests}

H.L. and U.N. hold stocks/options in Galecto Biotech AB, Sweden, a company developing galectin-3-targeting molecules.

\section{Authors' contributions}

ABS performed all the experiments except as otherwise noted. JFR prepared a-synuclein monomers and aggregates. TD took the pictures using Transmission Electron Micrograph (T.E.M) and JFR performed the a-synuclein characterization using Western Blot. NR performed intracerebral injections and analyzed microglial galectin-3 immunoreactivity. MAB performed BV2 cells knockdown and measure iNOS levels. ABS, TD, JFR, MAB and JLV designed the study, analyzed and interpreted the data. All authors discussed the results and commented on or edited the manuscript. The first draft of the paper was written by ABS and then TD, JFR, PB, MBS and JLV discussed the results and commented on or edited the manuscript. All authors read and approved the final manuscript

\section{Acknowledgements}

We thank Dr. Sara Linse from Lund University for providing the a-synuclein plasmid construct. This work was supported by grants from the Swedish Research Council (2012-2229, 2012-4100), A.E. Berger, Gyllenstiernska Krapperup), the Royal Physiographic Society, Crafoord, Wiberg, G\&J Kock, Stohnes foundation, by Swedish governmental agency for innovation systems, VINNOVA, grant No. 2009-00236. By the European Research Council Advanced Award (PRISTINE-PD) to P.B., the Swedish Parkinson Foundation (Sweden), the Swedish Brain Foundation, the Human Frontier Science Program. Grant from Spanish Ministerio de Economia y Competitividad (SAF2012-39029). A.B.-S., J.F.R., N.L.R., P.B. and

T.D. are active in Bagadilico (Linné consortium sponsored by the Swedish Research Council) and the Strong Research Environment Multipark (Multidisciplinary research in Parkinson's disease at Lund University).

\section{Author details}

${ }^{1}$ Experimental Neuroinflammation Laboratory, BMC, Lund University, 22184 Lund, Sweden. ${ }^{2}$ Neuronal Survival Unit, BMC, Lund University, 22184 Lund, Sweden. ${ }^{3}$ Translational Parkinson's Disease Research, Center for

Neurodegenerative Science, Van Andel Institute, Grand Rapids, MI, USA. ${ }^{4}$ Department of Oncology-Pathology, Cancer Centrum Karolinska, Karolinska Institutet, 17176 Stockholm, Sweden. ${ }^{5}$ Departamento de Bioquímica y Biología Molecular, Universidad de Sevilla, Facultad de Farmacia, Sevilla, Spain. 'Section MIG, Department of Laboratory Medicine, Solvegatan 23, Lund University, 22362 Lund, Sweden. ${ }^{7}$ Centre for Analysis and Synthesis, Department of Chemistry, Lund University, PO Box 124, 22100 Lund, Sweden. 'Laboratoire d'Enzymologie et Biochimie Structurales, CNRS, Bat 34 Avenue de la Terrasse, 91198 Gif-sur-Yvette, France.

Received: 1 September 2014 Accepted: 17 October 2014 Published online: 12 November 2014

\section{References}

1. Chaudhuri KR, Schapira AH (2009) Non-motor symptoms of Parkinson's disease: dopaminergic pathophysiology and treatment. Lancet Neurol 8:464-474

2. Spillantini MG, Schmidt ML, Lee VM, Trojanowski JQ, Jakes R, Goedert M (1997) Alpha-synuclein in Lewy bodies. Nature 388:839-840

3. Qiao S, Luo JH, Jin JH (2012) Role of microglial activation induced by alphasynuclein in pathogenesis of Parkinson's disease. Zhejiang Da Xue Xue Bao Yi Xue Ban 41:210-214

4. Ross OA, Braithwaite AT, Skipper LM, Kachergus J, Hulihan MM, Middleton FA, Nishioka K, Fuchs J, Gasser T, Maraganore DM, Adler CH, Larvor L, Chartier-Harlin MC, Nilsson C, Langston JW, Gwinn K, Hattori N, Farrer MJ 
(2008) Genomic investigation of alpha-synuclein multiplication and parkinsonism. Ann Neurol 63:743-750

5. Kruger R, Kuhn W, Muller T, Woitalla D, Graeber M, Kosel S, Przuntek H, Epplen JT, Schols L, Riess O (1998) Ala30Pro mutation in the gene encoding alpha-synuclein in Parkinson's disease. Nat Genet 18:106-108

6. George JM, Jin H, Woods WS, Clayton DF (1995) Characterization of a novel protein regulated during the critical period for song learning in the zebra finch. Neuron 15:361-372

7. Stefanis L (2012) alpha-Synuclein in Parkinson's disease. Cold Spring Harbor Perspect Med 2:a009399

8. Kholodilov NG, Neystat M, Oo TF, Lo SE, Larsen KE, Sulzer D, Burke RE (1999) Increased expression of rat synuclein in the substantia nigra pars compacta identified by mRNA differential display in a model of developmental target injury. J Neurochem 73:2586-2599

9. Bendor JT, Logan TP, Edwards RH (2013) The function of alpha-synuclein Neuron 79:1044-1066

10. Shin EC, Cho SE, Lee DK, Hur MW, Paik SR, Park JH, Kim J (2000) Expression patterns of alpha-synuclein in human hematopoietic cells and in Drosophila at different developmental stages. Mol Cells 10:65-70

11. Lee HJ, Bae EJ, Lee SJ (2014) Extracellular alpha-synuclein-a novel and crucial factor in Lewy body diseases. Nat Rev Neurol 10:92-98

12. George S, Rey NL, Reichenbach N, Steiner JA, Brundin P (2013) alphaSynuclein: the long distance runner. Brain Pathol 23:350-357

13. Olanow CW, Brundin P (2013) Parkinson's disease and alpha synuclein: is Parkinson's disease a prion-like disorder? Mov Disord 28:31-40

14. Dunning CJ, George S, Brundin P (2013) What's to like about the prion-like hypothesis for the spreading of aggregated alpha-synuclein in Parkinson disease? Prion 7:92-97

15. Villar-Cheda B, Dominguez-Meijide A, Joglar B, Rodriguez-Perez Al, Guerra MJ, Labandeira-Garcia JL (2012) Involvement of microglial RhoA/Rho-kinase pathway activation in the dopaminergic neuron death. Role of angiotensin via angiotensin type 1 receptors. Neurobiol Dis 47:268-279

16. Tomas-Camardiel M, Rite I, Herrera AJ, de Pablos RM, Cano J, Machado A, Venero JL (2004) Minocycline reduces the lipopolysaccharide-induced inflammatory reaction, peroxynitrite-mediated nitration of proteins, disruption of the blood-brain barrier, and damage in the nigral dopaminergic system. Neurobiol Dis 16:190-201

17. Codolo G, Plotegher N, Pozzobon T, Brucale M, Tessari I, Bubacco L, de Bernard M (2013) Triggering of inflammasome by aggregated alpha-synuclein, an inflammatory response in synucleinopathies. PLoS One 8:e55375

18. Kim C, Ho DH, Suk JE, You S, Michael S, Kang J, Joong Lee S, Masliah E, Hwang D, Lee HJ, Lee SJ (2013) Neuron-released oligomeric alpha-synuclein is an endogenous agonist of TLR2 for paracrine activation of microglia. Nat Commun 4:1562

19. Fellner $L$, Irschick $R$, Schanda K, Reindl M, Klimaschewski L, Poewe W Wenning GK, Stefanova N (2013) Toll-like receptor 4 is required for alphasynuclein dependent activation of microglia and astroglia. Glia 61:349-360

20. Rojanathammanee L, Murphy EJ, Combs CK (2011) Expression of mutant alpha-synuclein modulates microglial phenotype in vitro. J Neuroinflammation 8:44

21. Gordon S, Pluddemann A (2013) Tissue macrophage heterogeneity: issues and prospects. Semin Immunopathol 35:533-540

22. Roodveldt C, Labrador-Garrido A, Gonzalez-Rey E, Lachaud CC, Guilliams T, Fernandez-Montesinos R, Benitez-Rondan A, Robledo G, Hmadcha A, Delgado M, Pozo D (2013) Preconditioning of microglia by alpha-synuclein strongly affects the response induced by toll-like receptor (TLR) stimulation Plos one 8:e79160

23. De Pablos RM, Herrera AJ, Villaran RF, Cano J, Machado A (2005) Dopaminedependent neurotoxicity of lipopolysaccharide in substantia nigra. FASEB J 19:407-409

24. Zindler E, Zipp F (2010) Neuronal injury in chronic CNS inflammation. Best Pract Res Clin Anaesthesiol 24:551-562

25. Stirling DP, Cummins K, Mishra M, Teo W, Yong WW, Stys P (2013) Toll-like receptor 2-mediated alternative activation of microglia is protective after spinal cord injury. Brain 137:707-723

26. Venero JL, Burguillos MA, Brundin P, Joseph B (2011) The executioners sing a new song: killer caspases activate microglia. Cell Death Differ 18:1679-1691

27. Jiang HR, Al Rasebi Z, Mensah-Brown E, Shahin A, Xu D, Goodyear CS, Fukada SY, Liu FT, Liew FY, Lukic ML (2009) Galectin-3 deficiency reduces the severity of experimental autoimmune encephalomyelitis. J Immunol 182:1167-1173
28. Pajoohesh-Ganji A, Knoblach SM, Faden Al, Byrnes KR (2012) Characterization of inflammatory gene expression and galectin-3 function after spinal cord injury in mice. Brain Res 1475:96-105

29. Seetharaman J, Kanigsberg A, Slaaby R, Leffler H, Barondes SH, Rini JM (1998) X-ray crystal structure of the human galectin-3 carbohydrate recognition domain at 2.1-A resolution. J Biol Chem 273:13047-13052

30. Leffler H, Carlsson S, Hedlund M, Qian Y, Poirier F (2004) Introduction to galectins. Glycoconj J 19:433-440

31. Shin T (2013) The pleiotropic effects of galectin-3 in neuroinflammation: a review. Acta Histochem 115:407-411

32. Jeon SB, Yoon HJ, Chang CY, Koh HS, Jeon SH, Park EJ (2010) Galectin-3 exerts cytokine-like regulatory actions through the JAK-STAT pathway. J Immunol 185:7037-7046

33. Karlsson A, Christenson K, Matlak M, Bjorstad A, Brown KL, Telemo E, Salomonsson E, Leffler H, Bylund J (2009) Galectin-3 functions as an opsonin and enhances the macrophage clearance of apoptotic neutrophils. Glycobiology 19:16-20

34. Lalancette-Hebert M, Swarup V, Beaulieu JM, Bohacek I, Abdelhamid E, Weng YC, Sato S, Kriz J (2012) Galectin-3 is required for resident microglia activation and proliferation in response to ischemic injury. J Neurosci 32:10383-10395

35. Lepur A, Carlsson MC, Novak R, Dumic J, Nilsson UJ, Leffler H (1820) Galectin-3 endocytosis by carbohydrate independent and dependent pathways in different macrophage like cell types. Biochim Biophys Acta 2012:804-818

36. Liu FT, Rabinovich GA (2010) Galectins: regulators of acute and chronic inflammation. Ann N Y Acad Sci 1183:158-182

37. Sano H, Hsu DK, Apgar JR, Yu L, Sharma BB, Kuwabara I, Izui S, Liu FT (2003) Critical role of galectin-3 in phagocytosis by macrophages. J Clin Invest 112:389-397

38. Lee HJ, Suk JE, Bae EJ, Lee SJ (2008) Clearance and deposition of extracellular alpha-synuclein aggregates in microglia. Biochem Biophys Res Commun 372:423-428

39. Yang RY, Hsu DK, Liu FT (1996) Expression of galectin-3 modulates T-cell growth and apoptosis. Proc Natl Acad Sci U S A 93:6737-6742

40. Colnot C, Ripoche MA, Milon G, Montagutelli X, Crocker PR, Poirier F (1998) Maintenance of granulocyte numbers during acute peritonitis is defective in galectin-3-null mutant mice. Immunology 94:290-296

41. Doverhag C, Hedtjarn M, Poirier F, Mallard C, Hagberg H, Karlsson A, Savman K (2010) Galectin-3 contributes to neonatal hypoxic-ischemic brain injury. Neurobiol Dis 38:36-46

42. Deierborg T (2013) Preparation of primary microglia cultures from postnatal mouse and rat brains. Methods Mol Biol 1041:25-31

43. Grey M, Linse S, Nilsson H, Brundin P, Sparr E (2011) Membrane interaction of alpha-synuclein in different aggregation states. J Parkinsons Dis 1:359-371

44. Saksida T, Nikolic I, Vujicic M, Nilsson UJ, Leffler H, Lukic ML, Stojanovic I, Stosic-Grujicic S (2013) Galectin-3 deficiency protects pancreatic islet cells from cytokine-triggered apoptosis in vitro. J Cell Physiol 228:1568-1576

45. Volarevic V, Milovanovic M, Ljujic B, Pejnovic N, Arsenijevic N, Nilsson U, Leffler H, Lukic ML (2012) Galectin-3 deficiency prevents concanavalin A-induced hepatitis in mice. Hepatology 55:1954-1964

46. Mackinnon AC, Gibbons MA, Farnworth SL, Leffler H, Nilsson UJ, Delaine T, Simpson AJ, Forbes SJ, Hirani N, Gauldie J, Sethi T (2012) Regulation of transforming growth factor-beta1-driven lung fibrosis by galectin-3. Am J Respir Crit Care Med 185:537-546

47. Rey NL, Petit GH, Bousset L, Melki R, Brundin P (2013) Transfer of human alpha-synuclein from the olfactory bulb to interconnected brain regions in mice. Acta Neuropathol 126:555-573

48. Ghee M, Melki R, Michot N, Mallet J (2005) PA700, the regulatory complex of the 265 proteasome, interferes with alpha-synuclein assembly. FEBS J 272:4023-4033

49. Henn A, Lund S, Hedtjarn M, Schrattenholz A, Porzgen P, Leist M (2009) The suitability of BV2 cells as alternative model system for primary microglia cultures or for animal experiments examining brain inflammation. Altex 26:83-94

50. Blandini F (2013) Neural and immune mechanisms in the pathogenesis of Parkinson's disease. J Neuroimmune Pharmacol 8:189-201

51. Tokuda T, Qureshi MM, Ardah MT, Varghese S, Shehab SA, Kasai T, Ishigami N, Tamaoka A, Nakagawa M, El-Agnaf OM (2010) Detection of elevated levels of alpha-synuclein oligomers in CSF from patients with Parkinson disease. Neurology 75:1766-1772

52. Reyes JF, Rey NL, Bousset L, Melki R, Brundin P, Angot E (2014) Alphasynuclein transfers from neurons to oligodendrocytes. Glia 62:387-398 
53. Bae EJ, Lee HJ, Rockenstein E, Ho DH, Park EB, Yang NY, Desplats P, Masliah E, Lee SJ (2012) Antibody-aided clearance of extracellular alpha-synuclein prevents cell-to-cell aggregate transmission. J Neurosci 32:13454-13469

54. Roodveldt C, Labrador-Garrido A, Gonzalez-Rey E, Fernandez-Montesinos R, Caro M, Lachaud CC, Waudby CA, Delgado M, Dobson CM, Pozo D (2010) Glial innate immunity generated by non-aggregated alpha-synuclein in mouse: differences between wild-type and Parkinson's disease-linked mutants. PloS one 5:e13481

55. Spencer B, Michael S, Shen J, Kosberg K, Rockenstein E, Patrick C, Adame A, Masliah E (2013) Lentivirus mediated delivery of neurosin promotes clearance of wild-type alpha-synuclein and reduces the pathology in an alpha-synuclein model of LBD. Mol Ther 21:31-41

56. Sanchez-Guajardo V, Barnum CJ, Tansey MG, Romero-Ramos M (2013) Neuroimmunological processes in Parkinson's disease and their relation to alpha-synuclein: microglia as the referee between neuronal processes and peripheral immunity. ASN Neuro 5:113-139

57. Schwartz M, Kipnis J, Rivest S, Prat A (2013) How do immune cells support and shape the brain in health, disease, and aging? J Neurosci 33:17587-17596

58. Suk K, Ock J (2012) Chemical genetics of neuroinflammation: natural and synthetic compounds as microglial inhibitors. Inflammopharmacology 20:151-158

59. Kobayashi K, Imagama S, Ohgomori T, Hirano K, Uchimura K, Sakamoto K, Hirakawa A, Takeuchi H, Suzumura A, Ishiguro N, Kadomatsu K (2013) Minocycline selectively inhibits M1 polarization of microglia. Cell Death Dis 4:e525

60. Surace MJ, Block ML (2012) Targeting microglia-mediated neurotoxicity: the potential of NOX2 inhibitors. Cell Mol Life Sci 69:2409-2427

61. Vafeiadou K, Vauzour D, Spencer JP (2007) Neuroinflammation and its modulation by flavonoids. Endocr Metab Immune Disord Drug Targets 7:211-224

62. Delacour D, Koch A, Jacob R (2009) The role of galectins in protein trafficking. Traffic 10:1405-1413

63. Carlsson S, Carlsson MC, Leffler H (2007) Intracellular sorting of galectin-8 based on carbohydrate fine specificity. Glycobiology 17:906-912

64. Kang BY, Kim E, Kim TS (2005) Regulatory mechanisms and their therapeutic implications of interleukin-12 production in immune cells. Cell Signal 17:665-673

65. Rothe H, Hartmann B, Geerlings P, Kolb H (1996) Interleukin-12 geneexpression of macrophages is regulated by nitric oxide. Biochem Biophys Res Commun 224:159-163

66. Latz E, Xiao TS, Stutz A (2013) Activation and regulation of the inflammasomes. Nat Rev Immunol 13:397-411

67. Strowig T, Henao-Mejia J, Elinav E, Flavell R (2012) Inflammasomes in health and disease. Nature 481:278-286

68. Lee HM, Kang J, Lee SJ, Jo EK (2013) Microglial activation of the NLRP3 inflammasome by the priming signals derived from macrophages infected with mycobacteria. Glia 61:441-452

69. Hafner-Bratkovic I, Bencina M, Fitzgerald KA, Golenbock D, Jerala R (2012) NLRP3 inflammasome activation in macrophage cell lines by prion protein fibrils as the source of IL-1beta and neuronal toxicity. Cell Mol Life Sci 69:4215-4228

70. Freeman D, Cedillos R, Choyke S, Lukic Z, McGuire K, Marvin S, Burrage AM Sudholt S, Rana A, O'Connor C, Wiethoff CM, Campbell EM (2013) Alphasynuclein induces lysosomal rupture and cathepsin dependent reactive oxygen species following endocytosis. PLoS One 8:e62143

71. Sokolowski JD, Mandell JW (2011) Phagocytic clearance in neurodegeneration Am J Pathol 178:1416-1428

doi:10.1186/s40478-014-0156-0

Cite this article as: Boza-Serrano et al:: The role of Galectin-3 in

a-synuclein-induced microglial activation. Acta Neuropathologica Communications 2014 2:156.

\section{Submit your next manuscript to BioMed Central and take full advantage of:}

- Convenient online submission

- Thorough peer review

- No space constraints or color figure charges

- Immediate publication on acceptance

- Inclusion in PubMed, CAS, Scopus and Google Scholar

- Research which is freely available for redistribution

Submit your manuscript at www.biomedcentral.com/submit 